\title{
Refleksi Kritis atas Degradasi Autentisitas Masyarakat Media
}

\author{
Fajar Bayu Aji* \\ Departemen Filsafat, Fakultas Ilmu Pengetahuan Budaya, Universitas Indonesia, \\ Kampus UI Depok, Depok, Indonesia \\ E-mail: fajarbajig6@gmail.com \\ Naupal Asnawi \\ Departemen Filsafat, Fakultas Ilmu Pengetahuan Budaya, Universitas Indonesia, \\ Kampus UI Depok, Depok, Indonesia \\ E-mail:naupal.2015@gmail.com
}

\begin{abstract}
This article is an attempt to exemplify the flourish of social media in the midst community life. Arguably, it's briefly inseparable from the rule of capitalism as a global economic system that has spread the spectacle problem. By using the critical reflection and scientific method through introduction and description, it's therefore the author trace the correlation among capitalism, social media, and degradation of authenticity. The study found that social media has provided such a way for the public to show it off. This occurs in two forms, namely through commodities and experiences. Therefore, the exhibition community provided by social media tends to degrades in such way as the authenticity of people because of the urge to continue chasing shadows or illusions. So that, this study highly recommends the importance of being wise with social media in term of the way how to use it as needed. Indeed, they also have to keep a distance from social media in order to people could be critical as well as maintain their authenticity while prioritizing humanity realtions over its commodity.
\end{abstract}

Keywords: capitalism, social media, spectacle, authenticity

\begin{abstract}
Abstrak. Riset ini bertujuan menunjukkan bahwa perkembangan media sosial di tengah kehidupan masyarakat yang tidak dapat dilepaskan dari peran kapitalisme sebagai sebuah sistem ekonomi global yang telah menyebarkan permasalahan spectacle. Dengan menggunakan metode refleksi kritis dan metode pengetahuan melalui pengenalan dan deskripsi, peneliti menemukan adanya keterhubungan antara kapitalisme, media sosial, dan degradasi autentisitas. Studi ini menemukan bahwa media sosial telah memfasilitasi sedemikian rupa masyarakat untuk pamer. Ini terjadi dalam dua bentuk, yakni melalui komoditas barang dan pengalaman. Masyarakat pamer yang difasilitasi oleh media sosial ini kemudian mendegradasi sedemikian rupa autentisitas masyarakat karena dorongan untuk terus mengejar bayang-bayang atau ilusi. Atas dasar ini, penelitian ini merekomendasikan pentingnya bersikap bijak dengan media sosial dengan menggunakannya sesuai keperluan dan tetap menjaga jarak dengan media sosial supaya masyarakat media dapat bersikap kritis dan mempertahankan autentisitas dirinya dengan tetap mengutamakan relasi humanitas di atas relasi komoditas.
\end{abstract}

Kata Kunci: kapitalisme, media sosial, spectacle, otentisitas

*Penulis Korespondensi 


\section{PENDAHULUAN}

Peradaban manusia terus berkembang seiring dengan bagaimana sistem yang berada di sekitarnya turut berkembang. Dengan berkembangnya tekonologi, masyarakat dihadapkan dengan perubahan baru dalam bentuk media massa yang sebut media digital. Jika sebelum munculnya media sosial komunikasi terbatas pada hubungan yang bersifat media seperti televisi dan hubungan yang bersifat personal seperti telepon dan SMS (Miller, 2016), maka hadirnya internet memberikan keleluasaan bagi pengguna untuk membuat dan menyebarkan konten menjadi lebih masif dari sebelumnya.

Meskipun media digital, seperti media sosial berkembang dan memberikan kemajuan dalam akses informasi, bukan berarti hal ini tidak menimbulkan masalah. Dengan semakin, banyaknya konsumsi masyarakat terhadap media digital membuat bergesernya pandangan masyarakat tentang realitas dan kehidupan yang ideal.

Guy Debord mengembangkan pemikiran Karl Marx tentang masyarakat dengan pendekatan konsumsi masyarakat terhadap televisi dan media. Ketika Marx menitikberatkan pemikirannya pada alienasi masyarakat pada kondisi hubungan majikan dengan buruh, Debord menitikberatkan pemikirannya pada kondisi hubungan konsumsi-konsumer dan masyarakat media (Best \& Kellner, 1999). Ia menyatakan bahwa sejarah kehidupan sosial dapat dipahami sebagai penurunan dari being menjadi having dan dari having hingga appearing semata (Debord, 2004).

Debord kemudian melihat semakin parahnya kondisi masyarakat ini setelah munculnya media massa. Kondisi penurunan ini adalah bentuk dari commodity yang memulai proses kolonialisasi terhadap kehidupan sosial. Debord juga memberikan term baru, yaitu spectacle atau gambaran terbalik dari sosial di mana hubungan antara commodity sudah menggantikan hubungan antarmanusia. Spectacle bukanlah kumpulan dari gambaran, melainkan hubungan sosial yang termediasi oleh gambaran-gambaran. (Debord, 2004).

Objek spesifik dari penelitian ini adalah media sosial di era masyarakat digital/kontemporer. Penelitian ini menjelaskan adanya degradasi dalam kehidupan masyarakat kontemporer, yaitu hidup dalam kondisi appearing semata. Kondisi ini akan terus berkembang seiring dengan hadirnya spectacle di dalam kehidupan masyarakat pengguna media sosial sehingga menciptakan sebuah kondisi di mana manusia di dalam masyarakat kontemporer ini kehilangan autentisitasnya. Belakangan, banyak muncul fenomena di kalangan artis tak terkecuali artis Indonesia yang memamerkan kekayaan materilnya di media instagram, dan anehnya itu dinikmati oleh para nitizen. Fakta empiris ini telah menunjukkan bahwa sudah terjadi degradasi autentisitas dalam masyakarat media sehingga dalam melihat nilai sebuah realitas sebagai sebuah komoditi yang diukur dari kepemilikan akan barang.

Satu penelitian serupa mengenai media sosial pernah juga dilakukan oleh Aletta Norval (Norval, 2012) berjudul "Don't Talk Back!" - The Subjective Conditions of Critical Public Debate. Dalam penelitiannya, ia membahas bagaimana media sosial punya peran besar dalam menyuarakan soal politik, sedangkan riset ini fokus pada 
permasalahan spectacle yang hadir sebagai perpanjangan tangan dari sistem ekonomi kapitalisme itu sendiri dengan mengandalkan media sosial. Penelitian dengan menggunakan Debord untuk media sosial dilakukan oleh Putri (2016). Penelitian etnografi visual yang dilakukan Putri menemukan bahwa foto dalam realitas instagram tidak hanya sebagai sarana representasi, tapi juga memediasi bagi lahirnya "the spectacle society" masyarakat tontonan (lihat juga: Andreas, 2020). Dalam kajian media dan politik, Putri telah menganalisis Jokowi spectacle mendominasi media dan situs jejaring sosial di Indonesia.

Penelitian ini mengambil perspektif yang berbeda meskipun sama-sama menggunakan Guy Debord. Fokus analisisnya bukan hanya pada masyarakat tontonan, tapi bagaimana masyarakat tontonan itu, dalam konteks media sosial, mendegradasi autensitas masyarakat. Untuk memahami fenomena ini, penelitian berpijak pada pemikiran Marxisme dan Neo-Marxisme. Hardiman (Xemandros, 2010) menyatakan bahwa inti pemikiran Marxisme pada hakikatnya adalah pada teori pertentangan kelas antara pemilik modal dengan buruh dan persoalan infrastruktur dan suprastruktur

Marx menganggap bahwa sebuah suprastruktur terbentuk berdasarkan bagaimana infrastruktur bekerja di dalam masyarakat. Dalam sistem masyarakat kapitalistik di mana kelompok pemilik modal memiliki kuasa atas kelompok pekerja dalam infrastruktur, secara tidak langsung kelompok ini pula yang pada akhirnya membentuk suprastruktur. Hal ini yang kemudian memunculkan adanya hierarki sosial yang terjadi di dalam masyarakat dan puncaknya adalah munculnya alienasi.

Berdasarkan kondisi alienasi inilah Marx menyampaikan istilah fetisisme komoditas. Fetisisme komoditas adalah persepsi yang terjadi di dalam masyarakat yang tidak melihat hubungan sosial sebagai hubungan sosial semata, tetapi sebagai hubungan ekonomi di mana pasar bekerja.

Dalam pemikiran Marx, fetisisme awalnya lebih berkaitan dengan manusia, agama dan ketuhanan atau dengan kata lain adalah penyembahan. Dengan munculnya komoditas yang menjadi fetish di dalam masyarakat, membuat individuindividu mengejar sesuatu yang ideal dengan fetish-fetish komoditas di dalam sebuah masyarakat (Adian, 2011). Pandangan Marx ini kemudian dikembangkan oleh Georg Lukacs ke dalam konsep reifikasi.

Secara harfiah, reifikasi berarti "turn into a thing" atau dalam bahasa Indonesia "berubah menjadi sesuatu" (Hawkes, 2003). Perbedaan konsep reifikasi yang dihadirkan Lukacs dengan konsep fetisisme komoditas yang disampaikan Marx adalah Marx memandang bahwa fetisisme komoditas lebih berhubungan dengan bagaimana suprastruktur yang dihasilkan dari infrastruktur menghasilkan alienasi bagi kelompok pekerja, sedangkan Lukacs memberikan pendekatan yang lebih bersifat praktis, yaitu kesadaran palsu yang dihasilkan dalam kehidupan praktis oleh masyarakat kapitalis (Adian, 2011).

Reifikasi hadir di dalam hidup masyarakat kapitalis ketika individuindividu di dalam masyarakat tersebut merasa membutuhkan pemenuhan atas kehidupannya melalui komoditaskomoditas yang ada. Karena ada sisi membutuhkan, masyarakat diharuskan belajar untuk memenuhi kehidupannya dalam bentuk pertukaran komoditas. Maka dari itu, pertukaran-pertukaran komoditas sudah semestinya terjadi di dalam masyarakat kapitalisme karena 
reifikasi muncul sebagai dorongan bagi masyarakat tersebut untuk memenuhi kehidupannya.

Pendekatan reifikasi dari seorang Lukacs tidak terlepas dari konsep second nature yang sebelumnya disampaikan oleh Aristoteles. Dengan terus-menerusnya kegiatan masyarakat sehari-hari yang berjalan, kegiatan ini akan menjadi sebuah kebiasaan. Kebiasaan ini akan terus menerus terjadi sehingga individuindividu yang ada di dalam masyarakat tersebut akan menganggap kegiatan ini menjadi sebuah kegiatan natural, atau kegiatan yang sudah seharusnya terjadi (Hawkes, 2003). Dari konsep Georg Lukacs inilah, Debord memberikan perkembangan pemikiran lanjutan terhadap konsep reifikasi ini. Debord melihat bahwa media adalah sesuatu yang kemudian hadir sebagai second nature dalam kehidupan masyarakat kapitalis dan dengan media pula, melalui spectacle, sistem ekonomi kapitalisme terus-menerus mengakar sehingga terjadi alienasi masyarakat terhadap kehidupannya sendiri.

Guy Debord memulai pemikirannya pada masyarakat yang didominasi oleh kondisi modern dalam sisi produksi, kehidupan mereka hadir sebagai akumulasi besar dari spectacle. Semua hal yang dahulu dihidupi kini hanya berubah menjadi representasi atau gambarangambaran semata. Gambaran-gambaran yang terpisah dari segala aspek dalam hidup ini melebur ke dalam aliran kehidupan yang membuat keutuhan hidup tidak bisa dipulihkan kembali. Pandangan terpecah atas realitas ini lalu berkumpul kembali ke dalam sebuah pseudo-World yang terpisah dan hanya dapat dilihat. Spectacle adalah kebalikan konkret dari kehidupan, sebuah gerakan otonom dari sesuatu yang tidak hidup (Debord, 2004).
Spectacle tidak bisa dipahami hanya sebagai sebuah tipuan visual yang dihasilkan teknologi media massa atau hanya sebagai dekorasi ataupun sesuatu yang trivial di dalam masyarakat, ia justru hadir sebagai jantung bagi masyarakat itu sendiri, bahkan mengepidemikan modelmodel kehidupan sosial yang dianggap ideal. Dalam tulisannya, Debord menyatakan, "The spectacle presents itself as a vast inaccessible reality that can never be questioned. Its sole message is: what appears is good; what is good appears"(Debord, 2004).

Berkembangnya ekonomi kapitalisme juga mengakibatkan pada bergesernya nilai bertahan hidup atau survival. Debord memberikan dua istilah dalam hal ini, consumable survival atau pemenuhan dasar-dasar kehidupan yang dilakukan manusia sebelum berkembangnya ekonomi, dan augmented survival atau pemenuhan dasar kehidupan yang pada hakikatnya bukan sepenuhnya kebutuhan dasar manusia (Debord, 2004) . Hal ini tidak terlepas pada peran spectacle dalam melanggengkan narasi-narasi bahwa produk-produk mereka merupakan hal-hal yang perlu dimiliki dalam kehidupan tiap individu di dalam masyarakat.

Berdasarkan uraian di atas, maka rumusan masalah dalam penelitian ini adalah 1). Bagaimana spectacle bekerja sebagai perpanjangan tangan dalam kapitalisme kontemporer dengan mengandalkan media sosial?; dan 2) Mengapa media sekarang ini berfungsi sebagai komoditas yang menjadi penyebab munculnya degradasi autentitas pada masyarakat media?

Dengan menjawab kedua pertanyaan penelitian ini, penelitian ini diharapkan memberikan sumbangan terhadap studi-studi media sosial sosial yang telah ada dengan memberikan penekanan pada perspektif kritis. 
Utamanya, studi dengan menggunakan konsep spectacle-nya Debord yang belum banyak dilakukan. Padahal, kajian ini penting mengingat sifat media sosial sebagai bagian dari "rezim audio visual" di mana ruang bagi "tontonan" baru dan "masyarakat pamer" mudah terepresentasikan.

\section{METODE}

Penulis menggunakan dua metode dalam penelitian ini, metode pertama adalah metode refleksi kritis, dan metode kedua adalah metode pengetahuan melalui pengenalan dan deskripsi atau knowledge by acquaintance and description. Metode refleksi kritis dilakukan untuk mengkaji sumber-sumber yang ada secara mendalam untuk menemukan hubungan logis di antara teori dengan fenomena situs media sosial.

Metode pengetahuan melalui pengenalan dan deskripsi dilakukan untuk memberikan deskripsi dan pemahaman terhadap konsep spectacle yang dikemukakan Guy Debord beserta contohcontoh kasus yang terjadi di media sosial (Bagini \& Fosl, 2010). Dengan menggabungkan kedua metode itu, peneliti mendapatkan deskripsi yang utuh tentang fenomana masyarakat media sebagai akibat dari perkembangan spectacle

\section{HASIL DAN PEMBAHASAN}

\section{Media Sosial sebagai Cara Kerja Spectacle}

Dalam memahami media sosial sendiri kita harus bisa memahami bagaimana media sosial bekerja di dalam masyarakat. Pada dasarnya, media sosial adalah sebuah fasilitas atau layanan yang hadir di dalam ruang lingkup komunikasi dan proses komunikasi yang memiliki unsur-unsur dan alur yang penting yang dapat dilihat dalam gambar sebagai berikut:

\section{Source $\rightarrow$ encoding $\rightarrow$ message $\rightarrow$ channel $\rightarrow$ decoding $\rightarrow$ receiver}

(Xemandros, 2010)

Source atau sumber adalah awal dari proses komunikasi. Sumber memiliki dasar ide-ide awal dalam proses tersebut dan ide ini belum terbentuk menjadi sebuah kesatuan bahasa. Dengan segala ide yang ada, sumber kemudian mengolah atau melakukan proses encoding dan menjadikan ide-ide tersebut ke dalam bahasa. Setelah proses encoding bahasa ini, kemudian menjadi pesan atau message yang kemudian dalam proses penyaluran atau channeling akan dikirimkan dan melalui proses decoding dalam rangka menyerap pesan ke dalam ide oleh penerima pesan atau receiver.

Ada dua unsur utama yang menjadi karakter media sosial dalam persebaran informasinya, yaitu kecepatan dan sensasionalisme. Sekarang, masyarakat dapat mengetahui apapun yang terjadi di belahan dunia lainnya secara real time atau langsung. Unsur kedua adalah sensasionalisme. Sensasionalisme sangatlah dibutuhkan untuk menarik konsumen untuk membaca atau mengakses situssitus tertentu. Semakin banyak angka yang didapatkan maka semakin banyak keuntungan yang didapatkan para pencipta konten atau content creator di media sosial.

Dalam segi keuntungan, sebagian besar pendapatan dari para pencipta konten ini adalah iklan. Situs-situs seperti YouTube dan Facebook kini sudah menyediakan sebuah sistem di mana para pencipta konten dapat melakukan proses 
monetisasi, atau menguangkan kontenkonten mereka. Dengan persyaratan tertentu yang disediakan situs-situs ini, seseorang dapat mengiklankan konten mereka dari pengiklan yang sudah bekerja sama dengan situs-situs media sosial. Selain itu, beberapa merek pengiklan juga bisa mendatangi langsung pencipta konten di dalam media sosial berdasarkan angkaangka pengakses yang didapatkan pencipta konten, yang kemudian mengiklankan atau meng-endorse merek tersebut di dalam konten mereka.

Keuntungan juga dapat hadir dari beberapa pemberi dana atau investor melalui situs-situs donasi. Dengan keuntungan secara materi yang dapat diraih di dalam internet, media sosial khususnya, membuat banyak pencipta konten di media sosial berlomba-lomba untuk menciptakan konten dengan dua unsurnya yang menjadi ciri khas, yaitu kecepatan dan sensasionalisme.

Kebanyakan akun-akun dari pencipta konten di media sosial lebih mementingkan segi sensasionalisme untuk mendapatkan banyak angka pengikut dan komentar likes atau "suka" dari pengguna media social itu. Ini semua berkaitan dengan peringkat atau rating dari sebuah konten ciptaan para pencipta konten. Ketika sebuah akun di dalam situs media sosial mengeluarkan konten maka pengguna lain dapat memberikan like untuk menyatakan kesukaannya pada konten tersebut. Angka likes yang didapatkan sebuah akun media sosial akan dijadikan tolok ukur bagi akun-akun tersebut untuk mendapatkan iklan. Hal ini menciptakan kondisi di mana berbagai macam konten yang menunjukkan sensasionalisme untuk mendapatkan angka akses atau views (dalam YouTube lebih mementingkan watchtime atau waktu tonton) serta likes untuk mendapatkan iklan atau pemberi dana.
Dengan banyak munculnya sumber informasi yang hanya mengandalkan kecepatan dan sensionalisme, menghadirkan permasalahan seperti berita palsu atau fake news dan konten manipulatif untuk mendapatkan keuntungan bagi golongan-golongan tertentu.

Usaha-usaha manipulatif dari para pencipta konten untuk meraih keuntungan pernah dikritik oleh sebuah kanal YouTube, Nerd City. Ia pernah mengajukan kritik atau ketidaksukaannya terhadap konten-konten para model Instagram dari beberapa akun di dalam situs media sosial tersebut melalui seri video yang ia beri judul "The Try Hards". Try hards sendiri secara harfiah memiliki arti "berusaha dengan keras", namun Nerd City mendefinisikannya sebagai berikut.

"A person who puts a large amount of efforts into achieving a certain image, to the point where it is obviously contrived. Rather than achieving an image through genuine personality, the try-hard consciously attemps to fit a certain style through deliberate imitation." (City, 2017)

Definisi ini menjelaskan bahwa banyak dari pencipta konten di Instagram bahkan tidak ragu untuk mengubah bentuk badan, menggunakan pakaian-pakaian tertentu dan mengubah gambar untuk menunjukkan satu atau lebih bagian kehidupannya untuk memenuhi suatu kriteria agar bisa menjadi populer di media sosial. Secara khusus, Nerd City memberikan gambaran bahwa bokong adalah bagian tubuh terpenting dalam mendapatkan banyak pengikut di Instagram. Selebriti-selebriti perempuan dengan ukuran bokong yang lebih besar dibandingkan masyarakat umum akan cenderung memiliki pengikut dengan jumlah besar di Instagram. 
Hal ini justru berdampak bagi masyarakat dalam aktualisasi dirinya di media sosial. Nerd City juga menyatakan bahwa dalam beberapa waktu terakhir permintaan konsumen bedah plastik pada bagian bokong meningkat drastis dari $28 \%$ hingga 36\% (American Society of Plastic Surgeons., 2016). Hal ini tentu saja berkorelasi dengan bagaimana bentuk bokong menjadi hal penting di dalam sosialisasi di masa kini. Seseorang akan sulit untuk mengaktualisasikan dirinya jika ia tidak dapat mendapatkan banyak pengikut di media sosial, dan salah satu cara yang ampuh bagi perempuan untuk mendapatkan banyak pengikut adalah menunjukkan bokong yang besar.

\section{Masyarakat Spectacle Kontemporer}

Dalam tulisannya yang berjudul Comments on the Society of the Spectacle di akhir dekade 1980-an, Debord memberikan definisi akan spectacle sebagai berikut.

"...the autocratic reign of the market economy which had acceded to an irresponsible sovereignty, and the totality of new techniques of government which accompanied this reign" (Debord, 1990)

Dalam pemikiran ini, spectacle kemudian muncul sebagai sebuah tanda berkembangnya ekonomi pasar, atau sistem ekonomi kapitalisme, di dalam kehidupan masyarakat. Individu-individu di dalam masyarakat ini menjadi terdistorsi dari kehidupannya sendiri dan mulai mengejar nilai-nilai kehidupan yang dilandaskan pada konsumsi. Diawali dengan konsumsi akan komoditas tradisional seperti tiga kebutuhan pokok manusia, sandang pangan dan papan. Konsep dari konsumsi ini pun kemudian berkembang dengan kemunculan konsumsi informasi. Kehadiran dari konsumsi informasi ini tidak terlepas dari kemunculan media di tengah masyarakat.

Untuk memberikan pemahaman baru terhadap spectacle pada masyarakat pengguna media social di era 4.0 dan perbedaan mendasar dari masyarakat sebelumnya adalah terletak pada proses interaksi yang dapat diakses lebih mudah dengan adanya teknologi informasi.

Komoditas utama masyarakat spectacle kontemporer adalah informasi. Dengan adanya teknologi seperti komputer dan ponsel yang kini terhubung dengan teknologi jaringan internet, setiap individu yang memiliki akses terhadap teknologiteknologi ini sudah dipastikan dapat menjadi produsen sekaligus distributor dari komoditas dominan di dalam masyarakat spectacle.

Hal ini tentu saja menjadi sebuah permasalahan yang cukup krusial ketika semakin banyaknya titik acuan bagi individu-individu di dalam sebuah masyarakat untuk menjalankan kehidupannya. Spectacle dalam pemahaman Debord mendistorsi kehidupan individu di dalam masyarakat ke dalam sebuah kehidupan yang justru tidak menghidupinya dengan cara yang autentik. Masyarakat akan hidup di dalam upaya tiada akhir untuk mengejar bayang-bayang ideal yang seringkali disebarkan melalui media, dan kini media sosial.

Semenjak dicetuskan oleh Guy Debord, istilah spectacle akan selalu saling berkaitan dengan sistem ekonomi kapitalisme. Hal ini tidak terlepas dengan bagaimana media sebagai unsur utama dari spectacle dan kemunculan atau inovasi dari media tidak akan bisa dilepaskan dari bagaimana kapitalisme berkembang di dalam masyarakat. Banyaknya inovasi tidak akan terlepas dari adanya persaingan atau kompetisi dari kapitalisme itu sendiri. 
Pada masa kontemporer ini, media sosial sudah menjadi unsur yang cukup dominan bagi masyarakat yang hidup di dalamnya, spectacle terus berevolusi beriringan dengan bagaimana media dan kapitalisme yang berkembang di sekitarnya. Dengan segala kemudahan yang disajikan media sosial, membuat proses penciptaan konten tidak lagi dipegang sepenuhnya oleh pemilik modal perusahaan-perusahaan media. Masyarakat awam pun kini bisa menyebarkan pesan ataupun konten yang secara tidak langsung menyebarkan spectacle. Spectacle sendiri hadir di dalam masyarakat layaknya sebuah benang yang menghubungkan masyarakat yang kemudian menghasilkan sebuah gambaran ideal tertentu di dalam masyarakat tentang kehidupan masyarakat itu sendiri.

Cara kerja dari media sosial juga menentukan bagaimana spectacle dapat terus berada di dalam kehidupan masyarakat. Melalui pesan-pesan konsumtif yang seringkali disampaikan para produsen terhadap konsumen, para pencipta konten di media sosial menyampaikan pesan-pesan bermuatan kenikmatan hidup melalui kehidupan yang sangat konsumtif, seperti menggunakan pakaian ataupun perangkat dengan merekmerek tertentu untuk menunjukkan bahwa merek tersebut adalah sesuatu yang perlu dimiliki untuk menjalani kehidupan yang bahagia, layaknya para pencipta konten tersebut.

Banyak merek dagang seperti Supreme, Balenciaga, dan Yeezy kemudian meluncurkan banyak produk mereka layaknya produk-produk yang harus dikoleksi. Model bisnis yang seringkali digunakan pun menggunakan model limited edition, atau edisi terbatas. Model bisnis edisi terbatas adalah sebuah model bisnis di mana produsen, biasanya produsen ternama, meluncurkan sebuah model produk dengan batasan tertentu, batasan tersebut dapat berupa batasan waktu penjualan ataupun batasan jumlah produk.

Produk-produk yang dimunculkan dari model ini merangsang sisi hasrat konsumen untuk segera memilikinya sebagai aktualisasi image kehidupan yang ideal di mata public walaupun dengan harga yang cukup tinggi. Kondisi ini pun menciptakan sebuah kultur bernama hypebeast. Kultur ini bekerja layaknya spectacle bekerja di dalam masyarakat pengguna media sosial. Secara bahasa, hypebeast terdiri dari dua kata dalam bahasa Inggris, hype yang dapat diartikan sebagai sesuatu yang diantisipasi, trend yang memiliki arti gaya mutakhir, dan beast berarti orang yang terobsesi akan sesuatu. Jadi dapat diartikan bahwa hypebeast adalah sebuah kultur dengan obsesi akan trend-trend yang ada di dalam masyarakat (Urban Dictionary, 2011). Perusahaan pemilik merek dagang memanfaatkan kultur ini dan menjadi diuntungkan

Di balik keuntungan yang didapatkan oleh para kapitalis, tersimpan suatu problem besar dalam jiwa masyarakat, yaitu masyarakat terdegradasi dari realitas yang sebenarnya dan semakin kehilangan autentisas dirinya. Kontenkonten seperti "Berapa Harga Outfit Lo" adalah contoh terbaik untuk menunjukkan kultur hypebeast spectacle di dalam masyarakat. "Berapa Harga Outfit Lo" adalah sebuah genre konten video berbentuk wawancara kepada banyak pengguna pakaian dengan merek terkemuka yang dengan bangga mengenakannya untuk menunjukkan status sosialnya di masyarakat.

Tidak hanya komoditas barang, di era media sosial, muncul sebuah komoditas baru, yaitu experience atau pengalaman. Usaha-usaha baru ini tidak 
lagi menjual produk bagi para konsumennya, tetapi pengalaman akan suatu tempat atau acara di suatu tempat tersebut. Kemunculan komoditas ini tidak terlepas dari peran situs dan aplikasi media sosial yang membagikan berbagai macam pengalaman yang ia rasakan ke dalam akun-akun media sosial mereka dan kemudian mengajak followernya untuk dapat mendatanginya. Sebagai contoh dari komoditas ini adalah pop up experience. Konsep ini sesungguhnya adalah perpaduan dari dua konsep usaha yang sudah ada sebelumnya, yaitu pop up store dan museum. Pop up store secara definisi dapat dikatakan sebagai sebuah toko atau retail sementara yang menjual berbagai komoditas. Kemudian museum, sebuah institusi yang menyimpan, merawat dan mempertunjukkan barang, karya seni maupun artefak sejarah, untuk menyampaikan sebuah narasi konsep, peruntukan studi ataupun hiburan semata. Dari kedua konsep ini, pop up experience membentuk sebuah museum yang menunjukkan barang-barang yang masuk ke dalam satu narasi atau konsep besar secara tidak permanen. Contoh dari pop up experience ini adalah The Rose Mansion, Candytopia dan The Museum of Ice Cream.

Di balik konsep menarik yang disajikan pop up experience, model bisnis ini justru memunculkan sebuah kekosongan dalam segi makna. Sulit menemukan tujuan bagi konsumen untuk datang ke tempat-tempat ini selain untuk berfoto ria dan mengunggahnya ke situssitus media sosial.

Dengan konsep dan permainan warna menarik yang disajikan pop up experience, banyak pengunjung merasa tempat-tempat ini adalah destinasi yang harus diekspose di akun media sosial mereka semata sebagai penanda status sosial mereka. Amanda Hess, seorang kontributor dari The New York Times, menyampaikan kegelisahannya terhadap pop up experience yang justru tidak memberikan pengalaman yang disampaikan para konseptor dari tempattempat tersebut.

"By classifying these places as
experiences, their creators seem
to imply that something happens
there. But what? Most human
experiences don't have to
announce themselves as such.
They just do what they do. A film
tells a story. A museum facilitates
meaning between the viewer and
a work of art. Even a basic
carnival ride produces pleasing
physical sensations." (Hess, 2018)

Keluhan Hess akan pop up experience menunjukkan adanya masalah mendalam terhadap bagaimana komoditas pengalaman sudah masuk ke dalam masyarakat kontemporer. Mereka sudah tidak lagi memikirkan berapa banyak menghabiskan waktu dan uang mereka. Cara pandang ini juga menunjukkan bagaimana sebagian masyarakat sudah tidak merasa puas lagi hanya dengan komoditas barang. Banyak dari anggota masyarakat yang merasa kebahagiaan tidaklah semata-mata hanya didapatkan melalui barang-barang mewah dengan harga tinggi, melainkan sebuah pengalaman yang tidak dapat dilupakan. Dengan berkembangnya kultur hypebeast spectacle dan cara berpikir seperti ini, menandakan sudah munculnya proses degradasi dari manusia sebagai human being menjadi sebagai human having dan human appearing .

Dalam usaha untuk memahami masyarakat spectacle kontemporer beserta degradasi diperlukan sebuah pemahaman akan ciri dari masyarakat itu sendiri. Ciri ini pun muncul sebagai akibat dari adanya proses degradasi di mana masyarakat tidak lagi menghidupi kehidupannya, di mana 
being menjadi appearing semata. Dengan kehadiran media sosial layaknya sebuah upgrade dari media dalam segi partisipasi masyarakat, spectacle kemudian juga berkembang menjadi sebuah entitas yang lebih masif, tetapi masih memegang nilainilai serupa. Ciri pertama dari masyarakat spectacle kontemporer dapat terlihat dari bagaimana individu-individu di dalam masyarakat yang menjalani kehidupannya pada standar-standar gambaran ideal tertentu. Ciri ini tentu saja juga pernah disampaikan oleh Guy Debord dalam kalimat pertama bukunya, "The Society of the Spectacle", ia menyatakan sebagai berikut.

"In societies dominated by modern conditions of production, life is presented as an immense accumulation of spectacles. Everything that was directly lived has receded into a representation."(Debord, 2004)

Pemahaman Debord akan spectacle ini selain menggambarkan bagaimana kehidupan masyarakat dengan adanya media di dalam kehidupan mereka, juga menjelaskan bagaimana media sosial juga berperan dalam degradasi kehidupan manusia. Dengan adanya gambaran ideal ini, membuat individu di dalam masyarakat meninggalkan kehidupan autentiknya menjadi kehidupan yang sekadar mengejar gambaran ideal itu sendiri. Tidak akan menjadi masalah besar ketika seseorang memang mampu untuk melakukan hal-hal tersebut, tetapi ketika ia sesungguhnya tidak mampu dan memaksakan dirinya untuk terus mengonsumsi atau membeli barangbarang dan jasa untuk mengejar sesuatu yang ideal, maka hal ini sudah menjadi sesuatu yang sangat salah.

Ciri kedua adalah kehadiran media sosial di dalam masyarakat. Debord memaparkan pemahamannya akan spectacle tidak terlepas dari bagaimana media, terutama televisi, hadir di dalam kehidupan masyarakat. Berkembangnya media sosial di tengah masyarakat menjadikan spectacle berevolusi. Spectacle berkembang menjadi sesuatu yang lebih masif. Hal ini sangat berkaitan dengan bagaimana media sosial berfungsi di dalam masyarakat, media sosial memungkinkan berbagai macam pencipta konten untuk berbagi hal-hal yang berkaitan dengan kehidupannya. Tidak lagi seperti media yang membutuhkan modal besar, dengan rendahnya cost menciptakan sebuah kondisi di mana persebaran konten ataupun informasi semakin acak dan masif, membuat spectacle tidak lagi disebarkan oleh pihakpihak tertentu melainkan berbagai macam pihak.

Ciri ketiga dari masyarakat spectacle kontemporer adalah munculnya "pengalaman" atau experience sebagai komoditas baru di dalam masyarakat. Tidak seperti era sebelum kemunculan media sosial di mana komoditas seringkali diartikan dengan sesuatu yang material atau benda, kini pasar mulai menemukan komoditas baru. Komoditas ini muncul sebagai narasi perlawanan atau counterculture dari budaya yang konsumtif atas barang-barang yang dianggap mewah sebelumnya. Sebagian masyarakat merasa lelah dengan kehidupan yang berdasarkan kemewahan semata dan bagi mereka merasakan pengalaman adalah sesuatu yang tidak bisa digantikan dengan materi. Banyak dari mereka yang lebih memutuskan untuk berjalan-jalan keliling dunia dan merasakan kehidupan. Akan tetapi, cara berpikir ini memiliki kekurangannya tersendiri ketika pemilik modal mulai masuk untuk mengambil manfaat akan pasar baru yang muncul. 
Dengan adanya keinginan atau demand masyarakat akan kebutuhan untuk merasakan sebuah pengalaman, menciptakan sebuah kegiatan ekonomi baru seperti museum pop up atau pop up experience ataupun festival-festival dengan kesan kemewahan dan pengalaman sekali seumur hidup. Kemunculan praktik ekonomi ini menjadi sebuah pertanda bahwa pengalaman menjadi sebuah komoditas tersendiri yang tidak disebutkan Debord di dalam tulisannya. Akan tetapi, efek serupa terhadap kehidupan masyarakat tetap terjadi dengan sistem ekonomi kapitalisme masih menjadi unsur utama dalam praktik ekonomi ini.

Ciri keempat dari masyarakat spectacle kontemporer terletak pada alienasi kehidupan tiap individu di dalamnya. Di balik semua kemudahan yang diberikan media sosial, sistem teknososial ini justru membuat kesehatan mental banyak individu menjadi terganggu. Istilah seperti fear of missing out (FOMO) atau rasa takut akan ketertinggalan kabar menjadi sebuah subyek penelitian yang marak dibahas di dalam dunia penelitian khususnya psikologi dan ilmu komputer. Penelitian yang dilakukan di Universitas Pennsylvania, Amerika Serikat, yang menunjukkan bahwa semakin tingginya jangka waktu seseorang dalam menggunakan media sosial membuat orang tersebut lebih berpotensi untuk memiliki gejala depresi. Ditambah dengan penelitian yang dilakukan di Universtias York, Kanada, menunjukkan bahwa perempuan muda akan merasa minder ketika berinteraksi dengan orang-orang yang mereka anggap lebih atraktif di media sosial (Walton, 2018).

Kehadiran media sosial yang diharapkan dapat menghubungkan setiap penggunanya justru menciptakan adanya keterjarakan. Seorang pengguna lebih memiliki kemungkinan untuk merasakan alienasi yang dikarenakan adanya konsepsi ideal di sekitar mereka, bahwa mereka harus seperti ataupun melakukan satu atau dua hal yang sesungguhnya tidak harus untuk dijalani. Narasi-narasi ideal ini tidak terlepas dari bagaimana spectacle hadir di dalam masyarakat. Dengan semakin banyaknya sumber informasi pada media sosial membuat gambaran-gambaran yang ada semakin masif sehingga spectacle tetap langgeng di dalam masyarakat, bersamaan dengan kapitalisme sebagai sistem ekonominya.

\section{KESIMPULAN}

Berangkat dari rumusan masalah dan tujuan riset yang telah dipaparkan di bagian pendahuluan dapat diuraikan kesimpulan sebagai berikut.

Penelitian ini memberikan gambaran akan kehidupan manusia di dalam masyarakat kontemporer pengguna media sosial yang keberadaanya kini tidak bisa dipisahkan sebagai hasil perkembangan teknologi dengan dimensi kompetisi dan inovasi yang dimiliki kapitalisme global. Ia menciptakan sebuah kondisi di mana masyarakat tidak lagi dapat menghidupi kehidupannya secara autentik dan hanya mementingkan representasi atau semata sebagai tujuan di dalam kehidupan mereka. Spectacle hadir sebagai sesuatu gambaran yang menciptakan konsep ideal di dalam masyarakat.

Terlepas dari kebutuhan atas sebuah komoditas, spectacle kemudian hadir sebagai asuransi bagi para kapital agar komoditas-komoditas yang mereka jual akan terus dibeli. Spectacle merasuk ke dalam pikiran masyarakat melalui asumsi-asumsi kehidupan ideal, seakanakan apa yang ditampilkan di dalam media adalah sesuatu yang perlu dicapai dan untuk mencapai hal ideal tersebut 
diperlukan adanya konsumsi terhadap komoditas-komoditas di dalam media tersebut.

Media sosial pun menjadi ajang pamer kekayaan, seperti yang dilakukan oleh beberapa artis Indonesia belakangan ini melalui akun-akun instagram pribadinya dan anehnya itu disukai oleh para nitizen. Berkembangnya teknologi informasi lewat media social jelas mengubah cara pandang masyarkat media dalam menilai realitas, sehingga telah menyebabkan terjadinya degradasi autentisitas masyarakat media, dari being menjadi having dan akhirnya appearing. Kondisi ini cukup memprihatinkan karena relasi antara sesame manusia sudah direduksi menjadi relasi komoditas bukan lagi relasi humanitas.

Masyarakat kini dihadapkan pada sebuah kondisi di mana spectacle menjadi sangat masif sehingga untuk melepaskan jerat spectacle menjadi sebuah hal yang sangat sulit untuk dilakukan. Ketika banyak dari anggota masyarakat yang memutuskan untuk memisahkan diri dari segala komoditas barang-barang mewah dan menjalani kehidupan mereka melalui pengalaman atau experience, justru pengalaman kemudian menjadi sebuah komoditas menguntungkan bagi para kapital. Kondisi ini kemudian menciptakan sebuah kultur baru yaitu kultur komoditas dan kultur masyarakat konsumtif yang tidak lagi menjalankan kehidupannya sendiri, melainkan menghidupi kehidupannya atas dasar gambaran-gambaran tertentu dari nitizen, kultur masyarakat yang tidak lagi dapat membedekan antara realitas dengan simulasi, kultur masyarakat yang tidak bisa membedakan mana yang pencitraan dan mana yang asli. Bahkan berkat daya kreatifnya, masyarakat akan terus berada dalam jeratan sistem kapitalisme dengan spectacle sebagai salah satu sistem imun yang membuat sistem ekonomi ini terus berjalan, meskipun dengan modifikasimodifikasi tertentu. Sayangnya, masyarakat media tidak bisa keluar dari jebakan spectacle sehingga diperlukan adalah bersikap bijak dengan media sosial dengan menggunakannya sesuai keperluan dan tetap menjaga jarak dengan media sosial supaya masyarakat media dapat bersikap kritis dan mempertahankan autentisitas dirinya dengan tetap mengutamakan relasi humanitas di atas relasi komoditas. 


\section{Daftar Pustaka}

Adian, D. G. (2011). Setelah marxisme: Sejumlah teori ideologi kontemporer. Penerbit Koekoesan.

American Society of Plastic Surgeons. (2016). New statistics reflect the changing face of plastic surgery. American Society of Plastic Surgeons. https://www.plasticsurgery.org/news /press-releases/new-statisticsreflect-the-changing-face-of-plasticsurgery

Andreas, R. (2020). Instagram dalam perspektif masyarakat tontonan "Gejayan Memanggil." Jurnal Ilmu Dinamika Sosial, 4(1), 43-62. https://doi.org/10.38043/jids.v4i1.2 259

Bagini, J., \& Fosl, P. S. (2010). The philosopher's toolkit: A compendium of philosophical concepts and methods. Wiley-Blackwell.

Best, S., \& Kellner, D. (1999). Debord, cybersituations, and the interactive spectacle. Substance, 18(3), 129-156. https://doi.org/10.1353/sub.2006.00 02

City, N. (2017). Jen selter \& instagram's most popular body part models: How to get real followers for fake fitness! [Gambar Hidup].

Debord, G. (1990). Comments on the society of the spectacle. Verso.

Debord, G. (2004). The society of the spectacle. Rebel Press.
Hawkes, D. (2003). Ideology (Second Edi). Routledge.

Hess, A. (2018). The existential void of the pop-up "Experience." The New York Times.

https://www.nytimes.com/2018/o 9/26/arts/color-factory-museumofice-cream-rose-mansion-29roomscandytopia.html

Miller, D. (2016). What is social media? In How the World Change Social Media (pp. 1-8). UCL Press.

Norval, A. (2012). "Don't talk back!" - The subjective conditions of critical public debate. Sage Journal, 4O(6). https://doi.org/10.1177/0090591712 457662

Putri, E. (2016). Foto diri, representasi identitas dan masyarakat tontonan di media sosial instagram. Jurnal Pemikiran Sosiologi, 3(1), 80-98. https://doi.org/https://doi.org/10.22 146/jps.v3i1.23528

Urban Dictionary. (2011). Hypebeast. Urban Dictionary.

Walton, A. G. (2018). New studies show just how bad social media is for mental health. Forbes. https://www.forbes.com/sites/alic egwalton/2018/11/16/newresearchshows-just-how-badsocial-mediacan-be-for-mentalhealth\%oA

Xemandros, W. S. (2010). Hiperrealitas dalam iklan menurut pemikiran Jean Baudrillard. Universitas Indonesia. 
Jurnal komunikasi, Volume 14, Nomor 2, April 2020, Hal 169-182 